\title{
The Validation of the
} Writer's Prophetic Status in the Russian Literary Tradition: From Pushkin and Iazykov through Gogol to Dostoevsky

\author{
PAMELA DAVIDSON
}

\begin{abstract}
A
lthough it is widely recognized that the image of the writer as a prophetic figure has played an unusually prominent and persistent role in the development of the Russian literary tradition, this intriguing phenomenon has not received the close critical attention that it deserves. West European literary tradition provides a well-established context for the image, stretching from Homer and Virgil through Dante to Chenier, Blake, Byron, Hugo, Mickiewicz, and Nietzsche, to cite just some of the most obvious authors associated with prophecy. This broad framework clearly had an important influence on the Russian adoption of the image of the writer as prophet. Yet Russian writers took up this image in a substantially different and unique way.

What was the reason for this difference? Among several possible answers to this question, one stands out as most significant: following the failure of the Decembrist uprising, the Russian image of the writer as prophet underwent a fundamental transformation from an aesthetic, literary category (modeled on the classical and European tradition) into a spiritual and historical category (modeled on the biblical tradition). As a result of this shift, embracing the prophetic image came to be associated with espousing the "Russian idea" in one form or another. By and large, most Russian writers who took up an openly

This article forms part of a wider project on the development of the image of the writer as prophet in the Russian literary tradition. I am extremely grateful to the British Academy for the award of a two-year Research Readership in 1997-99 and to the Arts and Humanities Research Board for a grant for research leave in 2000-2001 that enabled me to investigate this topic.
\end{abstract}


prophetic stance in their works did so in relation to their understanding of Russia's spiritual and historical mission, tinged with messianic overtones. Defining the "Russian idea" served as a means of defining Russia's relation to the West, of establishing its place (as a relative latecomer) on the map of sacred history and European culture. Whatever form the ideal took (whether Slavophile or Westernizing, religious or secular, pro-Orthodox, proCatholic, or ecumenical), embracing it enabled its carrier to occupy a place in a tradition which could be traced back to the earliest formulations of national identity in eleventhcentury Rus', modeled on the Hebrew prophets' definition of the mission of the Jews. The promotion of a prophetic message in this tradition conferred upon a writer a considerable legacy of moral, spiritual, historical, and political authority - a factor which doubtlessly accounted in part for the strong appeal of the prophetic role.

The purpose of this article is not, however, to explore the content or resonance of the prophetic message in its manifold forms, but rather to investigate a key area in which the adoption of the prophetic image had a marked impact on the dynamics of the Russian literary process: the problem of validation of the writer's prophetic status. Any individual who subscribes to a tradition that claims to be prophetic, or who aspires to take up a place within it, must be able to demonstrate a belief that the legacy is genuine and can be traced back to an authentic point of origin. Russian writers who sought to model their literary tradition on the biblical ideal of prophecy found themselves confronted by this challenge. How were they to demonstrate the validity of the nascent tradition of literary prophecy that they were constructing? What strategies did they develop to validate their own prophetic status and that of other writers?

To achieve a broad view of the way in which this process of validation took shape, we shall focus on three key stages of its development from the time of Romanticism through to the latter part of the nineteenth century. Although the examples chosen are necessarily very selective, they are broadly representative of the tradition of validation as it unfolded and serve to highlight a number of its salient features. We shall begin by examining the relation to biblical tradition of a selection of poems written in the mid-1820s by Aleksandr Pushkin and Nikolai Iazykov; these texts are of particular significance as they were later invoked as authoritative evidence of the prophetic status of Russian literature. We shall then consider Nikolai Gogol's presentation of some of these poems in his Selected Passages from Correspondence with Friends (Vybrannye mesta iz perepiski s druz'iami, 1847). His method for establishing the image of the Russian poet as prophet, although largely focused on Iazykov, paved the way for the later, much fuller elaboration of Pushkin's prophetic significance by Fedor Dostoevsky, initiated in the 1870s and developed in his celebrated Pushkin speech of 1880. Dostoevsky's reading of Pushkin enabled him to assume the prophetic mantle that he chose to confer upon the poet. This marked a crucial and pivotal stage in the development of the tradition of validation of the Russian writer's prophetic status that was first set in motion in the 1820s. Dostoevsky, following Gogol's lead, was responsible for establishing the image of the writer as prophet within the context of a supporting canon; subsequent writers such as Vladimir Solov'ev and the religious symbolists extended and elaborated in their essays on theurgic aesthetics the method of validation of the writer's prophetic status that Dostoevsky had already set in place. 
Although it lies beyond the scope of this essay, we may note that this way of validating the writer's prophetic status continued to exert a powerful influence on the Russian literary tradition throughout the twentieth century. From the legacy of the symbolists it passed through the writings of the acmeists and the futurists into modernist and postmodernist prose. Its impact can also be traced in the formation of the official and unofficial canons of Socialist Realism and dissident literature; more recently it has resurfaced in the context of renewed debates about Russian national identity during the postSoviet period.

\section{THE VALIDATION OF THE PROPHET IN HEBREW TRADITION}

At each stage of the process outlined above, the claim for the prophetic status of Russian writers was justified by an appeal to biblical tradition. To appreciate the inevitable distortions that resulted from this transposition, we should first review the original source that Russian writers were emulating. How was the authenticity of prophets determined in Hebrew tradition? The essential characteristics that distinguish the true Hebrew prophet (who speaks the word that God has commanded in the name of God) from false prophets (who speak their own word in the name of God, or speak in the name of other gods) are clearly set out in the last book of the Pentateuch (Deut. 13:2-6; 18:15-22). The line through which the original prophetic gift was then transmitted is outlined in the opening verse of the tractate of the Mishna, Ethics of the Fathers: "Moses received the Torah from Sinai and transmitted it to Joshua; Joshua to the Elders; the Elders to the Prophets; and the Prophets transmitted it to the Men of the Great Assembly." Two fundamental principles emerge from this passage: the authenticity of the teaching of Moses, the greatest of the Hebrew prophets, is traced back to its divine origin, while its preservation is guaranteed by an unbroken chain of transmission.

A consequence of the divine origin of the prophetic calling is that the Hebrew prophet is unable to validate his own status. This explains why Moses was lost for words and fell on his face when Korah and his followers rose up to challenge his authority as leader of the people: he could only appeal to God to provide a visible sign of his divine election (Num. 16:4-7).

The way in which the prophetic gift was communicated to later successors is described in some detail on several occasions in Hebrew scriptures. The account of the transfer of Moses's leadership to Joshua highlights the three core elements of this process (Num. 27:15-23). When Moses learns of his impending death, his first request is that God should appoint a successor to replace him so that the people should not be "as sheep without a shepherd." God responds by instructing Moses to take Joshua, the son of Nun ("a man in whom is the spirit"), to lay his hand upon him, and to give him a charge. This act should be carried out publicly in the presence of the high priest and all the people, "so that all the congregation of the children of Israel may be obedient." The key elements of this sequence are emphasized once more in the closing verses of the Pentateuch, after the

${ }^{1}$ Pirkei Avoth 1:1. The Mishna was compiled at the end of the second century. 
account of Moses's death (Deut. 34:9). It is clear from both sources that the appointment of the new prophet was validated by a potent combination of divine selection, personal endorsement by an established prophet, and public recognition.

The same triad is present in the account of Elisha's succession to Elijah (2 Kings 115). When the time comes for Elijah to be taken up to heaven by God, the prophet travels first to Beth-el, then to Jericho, and finally to Jordan. At each stage of his journey he is accompanied by his disciple Elisha, who refuses to be parted from him. At the first two places, a company of "sons of the prophets" comes forth to speak to Elisha of his master's impending departure. Fifty of these prophets accompany the two men from Jericho to Jordan and witness what follows. Elijah removes his mantle and smites the river Jordan with it; the waters part and the two men cross over on dry land. When Elijah asks Elisha what he can do for him before he is taken away, Elisha asks to be given a "double portion" of his spirit. The chariot and horses of fire then appear and Elijah is taken up to heaven by a whirlwind. After witnessing this sight, Elisha cries out and rends his clothes. He takes up Elijah's fallen mantle and smites the Jordan; as before, the waters part and he crosses over. The assembled sons of the prophets, who have observed this scene from afar, now proclaim that the spirit of Elijah rests on Elisha and bow down before him as a sign of recognition and obedience. As in the description of Joshua's succession to Moses, the transfer of spirit from master to disciple is accompanied by tangible signs, given by the departing prophet to his successor and witnessed by a large gathering.

In both these accounts, the status of the new prophet is confirmed on three levels: by divine selection, by an established prophet, and by public recognition. Were all three elements essential to the process of validation? Divine selection, closely bound up with the prophet's own moral purity, was clearly indispensable. The second element, however, was optional and could vary according to circumstance; a new prophet might well arise at a time or place where no established prophet existed. The final element of public recognition always played a role, since the prophet's message to the people and its reception formed an integral part of his mission.

\section{THE TRANSPOSITION OF THE BIBLICAL MODEL OF PROPHETIC VALIDATION INTO THE RUSSIAN LITERARY TRADITION}

To what extent were Russian writers able to apply this model to the authentication of their own tradition of literary prophecy? Before examining the specific strategies adopted by individual writers, we should first consider in more general terms the various ways in which each of the three forms of validation were adapted when translated into a literary context.

The first form of validation posed a particular problem. Divine selection could not easily be demonstrated; it could only be suggested or somehow implied. But how? Vasilii Rozanov raised this difficulty in his assessment of Vladimir Solov'ev's status: what was the reclusive prophet to do? He could hardly arrive at a formal dinner, sit down, and casually announce: "Gentlemen, do you know? I am a prophet, there is something priestly 
and prophetic in me."' In the absence of open, divine selection, two qualities were therefore regularly invoked as substitutes: poetic inspiration and/or mystic experience were presented as evidence of contact with the divine, transcendent realm.

The second principle - the endorsement of a new prophet by an earlier established prophet - was actively embraced but severely distorted in the process. Its practical implementation presented several difficulties. Who was to play the role of the original "validating" prophet in the Russian literary tradition? As the founding father of modern Russian literature, Pushkin was almost invariably called upon to fill this post, despite his manifest unsuitability for it. Much effort, therefore, was expended on equipping him with the necessary credentials of the poet-prophet; typical strategies involved representing his poetic inspiration as a type of divine calling, salvaging his inadequate moral profile through allusions to his martyrdom in life and death, and providing him with the national or universal "message" that he so clearly lacked.

Once Pushkin was established in this role, it remained to trace the unfolding of the initial prophetic potential through subsequent generations. Since writers are not able to bestow their talents directly upon their contemporaries, the prophetic gift tended to be communicated through a chain of writers, separated by one or more generations. In practice this meant that the process was played out in reverse chronological sequence. Instead of an established prophet initiating the process of validation and transferring his gift to a younger contemporary, the later prophet had to seek out his own retrospective endorsement. This would usually involve refashioning the image of the earlier writer in a prophetic light, in order to carve out a niche for the new incumbent to occupy.

The third form of validation was also subject to substantial change. In biblical times, public recognition had a clearly defined pragmatic function: to spread among the people an awareness and acceptance of the earlier prophet's successor and thereby ensure obedience to the new prophet. Transferred to a literary context, recognition took on a quite different complexion, usually defined by the writer's desire for fame and adulation. Popular recognition could now be actively cultivated; indeed, the most effective method for the literary prophet to increase his following was to preach a message that the audience was already keen to hear.

The desire for recognition also affected the writer's choice of literary genre. Lyric poetry was invested with a higher degree of authority than prose and was therefore often cited as "proof" of prophetic qualities; it remained, however, an essentially private genre, which could not command such a broad public following. We therefore find that, although the Russian tradition of literary prophecy originated in verse, composed by poets such as Iazykov, Pushkin, Vil'gelm Kiukhel'beker, Fedor Glinka, Evgenii Baratynsky, Mikhail Lermontov, and Fedor Tiutchev, it was primarily articulated and developed in prose. Writers such as Gogol, Vissarion Belinsky, Dostoevsky, Vladimir Solov'ev, Viacheslav Ivanov, and Andrei Belyi chose a wide range of prose genres as their principal medium, including critical essays, public letters and diaries, philosophical tracts and novels; within this

${ }^{2}$ V. Rozanov, “Pis'ma Vlad. Serg. Solov'eva. Iz starykh pisem. Stat'ia (okonchanie), ' Zolotoe runo, 1907, no.3:54$62(61)$. 
context they made frequent reference to individual poems, quoted as authoritative sources for the prophetic tradition that they sought to demonstrate in their writings.

\section{THE POET AS PROPHET IN POEMS BY PUSHKIN AND IAZYKOV}

Given the special status accorded to poetry, we shall start our analysis of specific texts that played a key role in building up the tradition of validation by considering a few significant early sources from the verse of Pushkin and Iazykov. From the outset we should note an interesting paradox. The well-known canonical poems that later came to be cited as evidence of the writer's prophetic status were not in fact those in which the image of the poet as prophet first established itself. The early stages of this process of validation took place in a much more informal and personal context, with one poet conferring the title of prophet upon another as a gesture of literary recognition between friends. Iazykov, for example, most frequently took up the image of the poet as prophet in the context of his developing friendship with Pushkin. Between 1824 and 1826 both writers exchanged a series of poems, in which they defined their relationship as poets and friends. Pushkin initiated the dialogue before their first meeting; his first poetic address, "To Iazykov" (20 September 1824), took the form of a pressing invitation, urging the poet to come and visit him in exile at Mikhailovskoe. ${ }^{3}$ Pushkin promised him that (together with his cousin L. S. Pushkin) they would form a holy "trinity," inspired by wine, friendship, and poetry, and dedicated to the celebration of the "gifts of freedom":

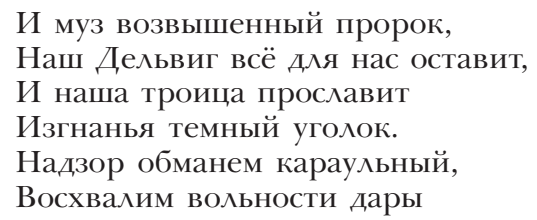

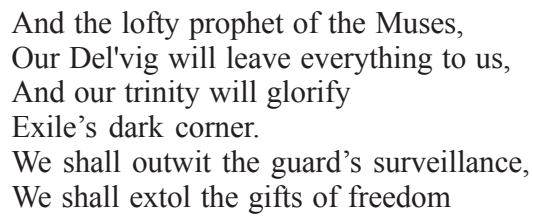

It was in this light-hearted, mildly heretical vein that the notion of the poet as prophet first entered Pushkin's poetic dialogue with Iazykov. Although his characterization of Anton Del'vig, a poet of his company, as the "lofty prophet of the Muses" might appear to signal a view of the poet as a prophetic figure, it is important to underline that this phrase is used in an aesthetic rather than biblical sense: for Pushkin, Del'vig was the prophet of the muses (in the Greek sense of the term prophetes - "one who speaks for"), not of God. Nonetheless, the explicit description of Del'vig the poet as a prophet, reinforced by playful allusions earlier in the poem to Pushkin as a frustrated prophet, set a significant precedent, which was later taken up and adapted in a different context. ${ }^{4}$

\footnotetext{
3"K Iazykovu" ("Izdrevle sladostnyi soiuz..."), in Pushkin, Polnoe sobranie sochinenii (PSS), ed. V. D. BonchBruevich, 17 vols. (1937-59; reprint ed. Moscow, 1994-97), 2/1:288-89 (text), 2/2:781-82 (variants), 2/2:1085 (notes).

${ }^{4}$ Pushkin toys with the image of frustrated prophet, lamenting the fact that his desire to take up his "tiazhelyi posokh" (ibid., 1. 12) in order to travel to join his friend was thwarted by the experience of persecution and exile. It is significant that lines 21-22, "Vsegda gonim, teper' v izgnan'i / Vlachu zakovannye dni" (variant: "Teper' odin, v glukhom izgnan'e / Vlachu tomitel'nye dni"), are later echoed in the opening lines of "The Prophet": "Dukhovnoi zhazhdoiu tomim, / V pustyne mrachnoi ia vlachilsia."
} 
When Iazykov replied to Pushkin's poem in his first address, "To A. S. Pushkin" (early 1825), he did not refer directly to the image of the poet as prophet, but emphasized the role of Pushkin's poem in validating his literary status and in conferring poetic immortality upon him:

\author{
В бытописаньи русских муз \\ Меня твое благоволенье \\ Предаст в другое поколенье, \\ И сталь плешивого косца, \\ Всему ужасная, не скосит \\ Тобой хранимого певца. ${ }^{5}$
}

\author{
In the annals of the Russian Muses \\ Your goodwill will convey me \\ To another generation, \\ And the steel of the bald reaper, \\ Dread by all, will not cut down \\ The poet preserved by you.
}

Iazykov eventually took up Pushkin's invitation to visit him and came to stay at Trigorskoe for six weeks during the summer of 1826. When he returned to Dorpat at the end of the summer, he sent Pushkin a letter, prefaced by a second poetic address, "To A. S. Pushkin" (16 August 1826). ${ }^{6}$ The opening lines announce his intention to commemorate "in fiery verse" the place and time of their "poetic union":

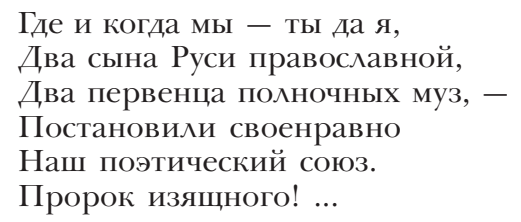

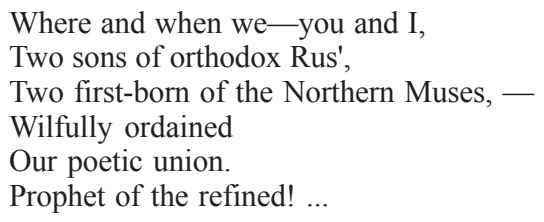

The poets' alliance has clearly broadened out beyond the framework of a purely personal friendship: they are now defined as the sons of a religious nation as well as the first-born initiators of a new poetic tradition. This context prepares for the bold apostrophe to Pushkin, addressed as a "prophet of the refined" and invited to share the poet's nostalgic reminiscences about how they "drank and drank" and "summoned freedom to our Rus'."

The characterization of Pushkin as a "prophet of the refined," like Pushkin's earlier reference to Del'vig as a "lofty prophet of the muses," is still a far cry from the fully fledged figure of the biblical prophet. Nevertheless, it is clear that the designation of a writer as prophet, although still couched in aesthetic terms, has now taken on a new historical and political resonance in the post-Decembrist context. This dimension was not lost on the censor, who prudently changed the description of Pushkin from "prophet of the refined" to the more innocuous phrase "bard of the refined" (pevets iziashchnogo) and also replaced the word "freedom" (svobodu) in the reference to the poets summoning freedom to Rus' with the politically more neutral term "art" (iskusstvo). ${ }^{7}$ Although Iazykov's reference to himself and Pushkin as "sons of Orthodox Rus"" was undoubtedly tinged with a certain degree of irony, the introduction of the theme of the poet's relation to national, religious

5"A. S. Pushkinu" ("Ne vovse chuia boga sveta..."), in N. M. Iazykov, Stikhotvoreniia i poemy, ed. K. K. Bukhmeier and B. M. Tolochinskaia (Leningrad, 1988), 132 (text), 519-20 (notes).

"A. S. Pushkinu" ("O ty, ch'ia druzhba mne dorozhe..."), in ibid., 183-84 (text), 531-32 (notes). For the text of the poem together with the letter, dated 19 August 1826, see Perepiska A. S. Pushkina, ed. V. E. Vatsuro et al., 2 vols. (Moscow, 1982), 2:190-91.

${ }^{7}$ For full details of the censor's changes see Iazykov, Stikhotvoreniia i poemy, 531. 
tradition provided a frame of reference that later writers such as Gogol and Dostoevsky were subsequently able to draw on in support of their own, more full-blooded, messianic presentation of the writer's prophetic role.

Pushkin replied to Iazykov's poem immediately with a flattering address, "To Iazykov" (28 August 1826), in which he noted the change that had taken place in the poet's style and inspiration. ${ }^{8}$ A few months later, Iazykov wrote a third, much longer (255 lines) poetic address to Pushkin, "Trigorskoe" (autumn 1826), first published in 1827 with the subtitle (later dropped) of "An Address to A. S. P." Pushkin was so impressed with this work that he arranged for its publication; $;^{10}$ as we shall see below, Gogol later quoted from it as evidence of Iazykov's special talent. The poem moves from a wide-ranging historical evocation of the genius loci to its symbolic value as the setting for a friendship based on freedom and poetry. Trigorskoe is hailed as:

Приют свободного поэта,

Не побежденного судьбой! (11.45-46)
The refuge of the free poet, Unvanquished by fate!

The later extended description of Iazykov's evenings of poetry and conversation with Pushkin is preceded by a more general section on the nature of friendship between poets. Here we may note the association between the freedom that poets enjoy through friendship and the power of their poetic discourse; this prepares for the comparison of poets to priests or prophets that follows:

Что восхитительнее, краше

Свободных, дружеских бесед,

Когда за пенистою чашей

С поэтом говорит поэт?

Жрецы высокого искусства,

Пророки воли божества!

Как независимы их чувства,

Как полновесны их слова! (11.131-38)
What is more delightful, more beautiful

Than free, friendly conversations,

When over a sparkling cup

A poet speaks with a poet?

Priests of high art,

Prophets of the divine will!

How independent are their feelings,

How full-weighted their words!

We can see from these poems that the image of the poet as prophet, introduced in the course of Pushkin's poetic dialogue with Iazykov, underwent a fairly clear progression from the specific and purely aesthetic (Pushkin's description of Del'vig as a "lofty prophet of the muses") through its broader application to Pushkin (addressed by Iazykov as a "prophet of the refined") to its final expansion into a universal category, open to all likeminded poets (characterized by Iazykov as "prophets of the divine will"). Thus, an image that was originally rooted in a private exchange gradually came to stand for poets in general, rather than for specific individuals. At all stages of this process of validation, poetry served as the means through which one poet could bestow the title of prophet upon another poet, or even upon himself, as in the case of Iazykov, who retrospectively awarded

${ }^{8}$ Pushkin, “K Iazykovu” (“Iazykov, kto tebe vnushil...”), PSS 3/1:22 (text), 3/1:576-77 (variants), 3/2:1128 (notes). ${ }^{9}$ Iazykov, “Trigorskoe (Poslanie k A. S. P.)," Stikhotvoreniia i poemy, 191-97 (text), 533-34 (notes).

${ }^{10}$ See Pushkin's letters to Iazykov, 9 November and 21 December 1826, in Perepiska A. S. Pushkina 2:192-95. 
himself the title of friendship's "own prophet" in his later poem on the death of Del'vig. ${ }^{11}$ In this way the tradition of validating the writer's prophetic status through poetry was established, although it should be emphasized that the use of the term "prophet" still remained predominantly classical at this stage, rather than biblical.

When later readers looked back to the poetry of this period for persuasive statements about the writer's prophetic role, they did not, however, turn to these personal exchanges, but preferred instead to cite more abstract texts on prophecy, which were more strongly rooted in biblical tradition. Two poems played a particularly important role in this respect: Iazykov's "The Genius" ("Genii," 10-19 May 1825) and Pushkin's “The Prophet" ("Prorok," 24 July-3 September 1826). These two works, although written at the same time and within the same context as the poetic addresses discussed above, were entirely devoid of personal references and therefore much more amenable to absorption into a more general, universal context.

Iazykov's "The Genius" provides a valuable example of an early attempt to transfer the biblical pattern of prophetic succession into literary tradition. The poem presents the account of Elijah's prophetic spirit passing over to Elisha as a model for the transmission of literary genius.

Когда, гремя и пламенея, Пророк на небо улетал Огонь могучий проникал Живую душу Елисея:

Святыми чувствами полна, Мужала, крепла, возвышалась, И вдохновеньем озарялась,

И Бога слышала она!

Так гений радостно трепещет,

Свое величье познает,

Когда пред ним гремит и блещет

Иного гения полет;

Его воскреснувшая сила

Мгновенно зреет для чудес ...

И миру новые светила -

Дела избранника небес! ${ }^{12}$
When, thundering and flaming, The prophet flew up to heaven A mighty fire penetrated

The living soul of Elisha:

Full of holy feelings,

It expanded, grew stronger, rose up,

And lit up with inspiration,

And heard God!

In the same way a genius thrills with joy,

Recognizes his own greatness,

When before him thunders and shines

The flight of another genius;

His resurrected power

Immediately ripens for miracles ...

And the deeds of the chosen one of the heavens Are new luminaries to the world!

The grafting of biblical tradition on to literature imparts a prophetic aura to the writer's calling, but carries with it a significant number of distortions, directly related to the problems of adaptation outlined in the preceding section. The first point to note is that the prophet's divine calling is transmuted into an image of poetic inspiration. The prophetic "fire" that Elijah transmits to Elisha resurfaces a few lines later as the "inspiration" that illuminates the disciple's soul. Although this inspiration is still linked to God in the last line of the first stanza, the second stanza is much more secular in tone: the "prophet" is replaced by the term "genius" and there are no more open references to the divine dimension.

\footnotetext{
${ }^{11}$ See the lines from "Na smert' Bar. A. A. Del'viga" (1831), in which Iazykov refers to himself in his student years: "Tam druzhba udalaia, / Ego ucha i odobriaia, / Svoim prorokom nazvala" (Stikhotvoreniia i poemy, 265-66 [text], 547 [notes]).

${ }^{12}$ Ibid., 153-54 (text), 526 (notes). I have restored the capital to "Boga," as in the original edition of 1833.
} 
There is also a significant shift of emphasis from the outgoing older prophet (the main focus of the original biblical account) to his successor. Iazykov's poem is written from the perspective of the younger prophet, Elisha, as he takes over from Elijah, rather than from that of the older prophet, who bestows the divine gift. This reflects the trend toward retrospective endorsement, widespread in the tradition of literary prophecy, as noted above. It is also linked to the loss of prophetic humility; the new genius clearly "recognizes his own greatness" and is proud of his elevation to prophetic status. Hence the emphasis on public recognition: at the end of the poem, the genius is presented as the "chosen one of the heavens," whose deeds light up the whole world.

This poem was originally entitled "The Envy of Genius" ("Zavist' geniia"). Iazykov evidently recognized the writer's endemic inclination toward pride and envy, but wished to counter these negative traits by describing the process of literary succession in terms related to the selflessness of biblical prophecy. Although the attempt to reconcile two different worlds resulted more in the dilution or distortion of the original spirit of biblical prophecy than in the intended elevation of literary inspiration, "The Genius" still retained its significance and impact as one of the earliest texts to represent the development of Russian literature in terms of the biblical tradition of prophecy. As we shall see below, the broad vision that it projected was eagerly seized upon by Gogol as proof of the essential congruity between the two traditions that he sought to demonstrate.

In the end, however, it was not Iazykov's poem but Pushkin's "The Prophet" which had the strongest and most lasting impact on the validation of the writer's prophetic status in the Russian literary tradition. This was due to a number of reasons. Most obviously, "The Prophet" is a far more memorable and powerful poem than "The Genius." Through its direct, unmediated presentation of the figure of the biblical prophet, it avoids the sense of dilution that accompanies Iazykov's attempt to translate biblical images into a literary idiom. Furthermore, as Pushkin's leading position in the canon of Russian literature gradually became established, his poem came to carry a much greater authority, eclipsing that of Iazykov's verse. Its status as the principal source text for the view of the poet as prophet is in fact so firmly fixed that it has seldom been challenged. Yet one crucial question must be asked. Why have Russian readers persistently read this poem as a text about the poet, despite the fact that it deals quite unambiguously with the figure of the biblical prophet, drawing on specific details from a well-known passage in Hebrew scriptures (Isa. 6:1-9)? On the surface this is baffling, as the poem contains no overt references to the poet. Why, therefore, is it invariably cited as evidence of Pushkin's endorsement of the poet's prophetic role, and sometimes even used to present its author as the very embodiment of the prophet described in his poem?

The answer would appear to lie in a combination of two factors: the original context from which "The Prophet" emerged, and its reinforcement through the expectations of later readers. Pushkin's poem was composed at some point between late July and early September 1826; during this time, as we have seen, he received Iazykov's second poetic address (dated 16 August 1826), hailing him as a "prophet of the refined."13 The

\footnotetext{
${ }^{13}$ It is not possible to establish whether Pushkin wrote "The Prophet" before or after receiving Iazykov's second poetic address. If "The Prophet" was written first, Pushkin may have shown it to Iazykov while the latter was staying
} 
numerous references to the poet as a prophet in the poetic dialogue of Pushkin and Iazykov as well as in the verse of the Decembrist poets, together with the broad programmatic statement offered in "The Genius," provided the immediate contemporary context within which Pushkin's "The Prophet" was taken up and interpreted as a poem about the poet's calling. An important role in this respect was also played by Pushkin's friend, the Polish romantic poet Adam Mickiewicz, who took the view that the poem reflected a peak (subsequently betrayed) in the poet's awareness of his prophetic vocation.

Pushkin himself was a remarkably precise poet, capable of echoing different poetic voices quite faithfully without eroding their specific differences. His verse embraces a wide range of different prophets: the poet as aesthetic prophet of the muses, the poet as unwitting prophet of the future ("André Chénier," 1825), the prophet of the Koran ("Imitations of the Koran," 1824), and the biblical prophet of Hebrew scriptures ("The Prophet," 1826, and "With Homer you conversed at length alone...," 1832). ${ }^{14}$ His readers, however, were generally less subtle and tended to merge these distinct voices into a single, undifferentiated whole, loosely bound together by the common incidence of the word "prorok" in each text. Curiously, exactly the same fate befell Pushkin's treatment of the image of the demon. Although his verse reflects a clear distinction between two different types of demons, the destructive demon of moral corruption (related to Christian tradition) and the benign daemon of artistic inspiration (derived from classical sources), later readers from Lermontov onward blurred these differences and created a single, composite demon, thereby giving rise to the tradition of art as demonic. ${ }^{15}$ In the same way, syncretic readings of Pushkin's poem about the biblical prophet alongside his references to literary prophets in the classical sense of the term caused their author to be represented as the founding father of the tradition of art as prophetic. It is truly remarkable that two of the most potent traditions in Russian culture - the view of art as prophetic or demonic - have been traced back to Pushkin and ostensibly sanctioned by his authority, despite the fact that they are both quite unPushkinian in spirit.

The prophetic view of the writer's mission was gradually reinforced by the growing trend toward a messianic interpretation of Russia's destiny. This tendency gathered momentum during the 1830s and 1840s and is clearly reflected in Iazykov's works. Although he styled himself in his first address to Pushkin as a "bard of Bacchanalian pictures," he subsequently changed his view of this period ("I was facile then!" he commented in a late letter to the poet). ${ }^{16}$ In the early 1830 s, under the influence of his new Moscow circle of friends (centered on his relations, the Kireevsky brothers, and including A. S. Khomiakov,

at Trigorskoe during the summer of 1826 . If it was written later, his treatment of the prophet may in part have been influenced by Iazykov's address to him as a prophet. Although the editor of Pushkin's Polnoe sobranie sochinenii places Pushkin's reply to Iazykov's second poetic address four poems before "The Prophet," this order is evidently based on the latest possible date of "The Prophet" and does not imply a definitive chronological sequence of composition.

${ }^{14}$ Pushkin, "Andrei Shen'e," "Podrazhaniia Koranu," and "S Gomerom dolgo ty besedoval odin...," PSS 2/1:352$56,2 / 1: 314-18$, and 3/1:286, respectively.

${ }^{15}$ On the development of this tradition see Pamela Davidson, "The Muse and the Demon in the Poetry of Pushkin, Lermontov, and Blok," in Russian Literature and its Demons, ed. Pamela Davidson (New York, 2000), 167-213.

${ }^{16}$ The phrase "pevets vakkhicheskikh kartin" occurs in "A. S. Pushkinu" (early 1825), in Iazykov, Stikhotvoreniia i poemy, 132. For Iazykov's later comment see his letter to Pushkin, 1 June 1836, in Perepiska A. S. Pushkina 2:200. 
who married his sister), he began to move toward the adoption of Slavophile beliefs, tinged with messianism. Around this time he composed "To the Poet" (1831), later signalling its importance by placing it at the head of his first collection of verse (1833). ${ }^{17}$ In a sense, by raising the notion of the poet as prophet onto a higher, more abstract plane, this poem rounds off the cycle of his earlier poetic exchanges with Pushkin. Although it contains no direct personal references to Pushkin, it takes up several images from "The Prophet" and incorporates them into a new programmatic definition of the poet's prophetic mission. "Inspiration" (vdokhnoven'e) is now rhymed with "mission" (prednaznachen'e); the poet who knows his "blessed path" (blagoslovennyi put') and can wield the "fiery word" (ognedyshashchee slovo) is enjoined to be bold "like an eagle" (kak orel) and to step forth into the world to spread his prophetic message:

\section{Иди ты в мир - да слышит он пророка}

Go forth into the world - may it hear the prophet

These reminiscences of "The Prophet" are followed by an explicit comparison of the ideal poet to the prophet David, who was able to calm King Saul with the sounds of his lyre. The deliberate incorporation of images from Pushkin's poem into this framework suggests that the projected vision of the poet as a biblical, prophetic figure, earlier advanced in "The Genius," was already being realized in Russian literature. In fact, Iazykov had already contributed to this process in the previous year by writing two "imitations" of psalms - donning the mask of the prophet David was a device that enabled him to align himself directly with the Hebrew prophets and to write freely of the poet's prophetic mission in this context. ${ }^{18}$

\section{GOGOL'S READING OF PUSHKIN AND IAZYKOV}

Although the process of building a literary tradition to support the ideal of the writer as prophet was first set in motion in verse, prose remained the most effective medium for consolidating this tradition and demonstrating the validity of its claims. The first writer to argue the case for such an approach in prose was Gogol; his critical writings of the 1840s served as a vital stepping-stone, bridging the gap between the poetry of the two previous decades and the later views of Dostoevsky.

Mindful of the special authority of verse, Gogol set out to demonstrate that Russian poets were the carriers of a unique prophetic spirit, derived from biblical tradition. Although he had hinted at Pushkin's potential relevance to future generations in his early essay "A Few Words about Pushkin" ("Neskol'ko slov o Pushkine," 1832) and continued in his later writings to refer to poems such as "The Prophet" as evidence of the poet's

\footnotetext{
${ }^{17}$ Iazykov, "Poetu," Stikhotvoreniia i poemy, 275-76 (text), 548 (notes).

${ }^{18}$ See "Podrazhanie psalmu XIV" (3 September 1830) and "Podrazhanie psalmu CXXXVI" (1830), in ibid., 25153 (texts), 545 (notes). In the first imitation, the comparison of the poet/psalmist to an "orel shirokokrylyi" can be seen as a conflation of the references to the "shestikrylyi serafim" and to the "ispugannaia orlitsa" in Pushkin's "Prorok." Iazykov republished both imitations alongside "Poetu" in his first collection of poems (1833). The series was concluded many years later with the much freer, autobiographical "Podrazhanie psalmu" (29 November 1844), in ibid., 349-50 (text), 560 (notes).
} 
prophetic qualities, he preferred to advance Iazykov, rather than Pushkin, as the leading contemporary representative of his ideal of the Russian poet-prophet. This choice was partly related to the content of Iazykov's verse, but also owed a great deal to the nature of Gogol's personal relationship with the poet.

The two writers first met in June 1839 in the German resort town of Hanau (between 1838 and 1843 Iazykov lived abroad, seeking treatment for his serious medical condition). Gogol visited his new friend once more in Hanau in September 1841; after his departure, he sent him the first of a long series of effusive letters, fondly imagining the house that they planned to share in Moscow ("with two secluded studies") and urging him to take up the prophetic "staff" (posokh) bequeathed to him by his mentor (Gogol had given him a walking stick as a symbolic parting gift):

Your path is firm, and as a pledge for these words it is not in vain that a staff was left for you. Oh, have faith in my words! ... I have not the strength to say to you anything but this: have faith in my words. I myself do not dare not to have faith in my words. ... Henceforth your gaze must be brightly and cheerfully lifted up to the mountain - this was the purpose of our meeting. And if at our parting, when we shook hands, a spark of my spiritual strength did not pass from my hand into your soul, then that means that you do not love me. ${ }^{19}$

Gogol's image of a spark of his spiritual strength being transmitted to his disciple echoes Iazykov's description in "The Genius" of the fire of the prophet Elijah penetrating the soul of his successor Elisha. As we shall see below, Gogol particularly admired this poem for its presentation of relations between writers in terms of the biblical model of prophetic succession. Although he was younger than Iazykov, he evidently cast himself in the role of "senior" prophet, extending spiritual and moral guidance to his successor.

In the autumn of 1841, after Gogol went back to Russia, Iazykov addressed a lengthy poem to him from Hanau, blessing his return "From this unchristian German realm / To Rus', to the holy shrine on the Moscow river" and concluding with an invitation to his "brother" to establish a "refuge" with him in Russia. ${ }^{20}$ Although the two friends later spent the winter of 1842-43 together in Rome, the experience of sharing a flat with Gogol nearly drove Iazykov to distraction and their plans to settle down together in Russia were soon abandoned. After Iazykov returned to Russia in August 1843, he did not see Gogol again but maintained a close correspondence with him until his death in 1847 .

Undeterred by this parting of the ways (or perhaps even spurred on by it), Gogol continued to represent his relationship with Iazykov as a key link in a chain of prophetic succession. In a series of letters, written to Iazykov after the latter's return to Russia, he constructed a leading role for himself as the poet's spiritual and literary mentor, offering him extensive and passionate instruction on a wide variety of subjects, including the

${ }^{19} \mathrm{Gogol}$, letter to Iazykov, 27 September 1841, in N. V. Gogol', Polnoe sobranie sochinenii (PSS), ed. N. L. Meshcheriakov et al., 14 vols. (Moscow, 1937-52), 11:346-47(347). The subsequent ups and downs of Gogol's infatuation with Iazykov can be traced through his letters to the poet, published in vols. 11, 12 and 13 of this edition. For an interpretation of the friendship as a manifestation of Gogol's homosexual orientation see Simon Karlinsky, The Sexual Labyrinth of Nikolai Gogol (Chicago, 1976), 211-25.

${ }^{20 “}$ "Nikolaiu Vasil'evichu Gogoliu," in Iazykov, Stikhotvoreniia i poemy, 330-31 (text), 556 (notes). 
efficacy of prayer, ways of combating illness, edifying religious reading, the divine origins and power of poetry, and fitting biblical themes for his verse.

As in the case of the poetic dialogue between Pushkin and Iazykov, Gogol's attribution of prophetic qualities to Iazykov took root and developed in the context of a personal friendship. Gogol took this one step further, however. To gain the element of public recognition that formed an important part of the validation of the prophet's status, he elevated his private relationship to a broader level of national significance by making selections from his private correspondence available to the general public in the form of a book. With this plan in mind, he reminded Iazykov in July 1846 to send him copies of two important letters that he had written to him in December 1844..$^{21}$ He then reworked these letters to form the chapter of Selected Passages from Correspondence with Friends (1847), didactically entitled "Subjects for a Lyric Poet in the Present Time." 22 Although the new version retained the dates of the original letters and remained faithful to them in spirit, the text was in fact almost entirely rewritten and considerably abridged.

Gogol's point of departure in both sections of the chapter, as in the original letters, was his ecstatic reaction to Iazykov's poem "The Earthquake" (18 April 1844). ${ }^{23}$ This rather solemn and pontifical work retells a miraculous legend concerning the divine origins of a prayer. During a terrible earthquake in Constantinople, an "invisible force" swept a youth up into the sky, where he heard the "heavenly speech" of angels ("Holy, holy, holy!" - the chant of the seraphim in Isaiah 6:3). When he returned to earth with this song, it was adopted by the Byzantine church as a prayer for the salvation of the faithful. In the final stanza, the poet is enjoined to imitate this youth: in times of troubles he should listen to the angels above and bring their heavenly prayers down to the trembling people below to ensure their salvation through faith.

The idea that the writer is the bearer of words of divine origin, which empower him to bring about the people's spiritual salvation, carried considerable appeal. According to Gogol, Vasilii Zhukovsky shared his delight in Iazykov's work and regarded it as one of the best of all Russian poems, offering a message that every Russian writer should follow. Gogol therefore urged Iazykov to turn to the Old Testament as his model for interpreting present events in the light of divine judgment. Filled with the spirit of the Bible, he should plumb the depths of Russian history and use this material to impress his message on the modern reader: "It is necessary that your verses should be perceived by everyone like the letters traced in the air that appeared to Belshazzar at the feast, provoking a sense of awe even before their meaning could be penetrated." ${ }^{24}$ The comparison of Iazykov's verse to the divine message interpreted by the prophet Daniel (Dan. 5) makes it plain that Gogol expected his friend to assume the role and style of the Hebrew prophetic writings.

The second section continues in the same vein and concludes with a passionate tirade, promising the poet divine inspiration if he follows his mentor's advice:

\footnotetext{
${ }^{21}$ For Gogol's letter to Iazykov of 22 July 1846 see Gogol', PSS 13:89. For his earlier letters to Iazykov of 2 and 26 December 1844 see ibid., 12:377-79 and 421-25.

22“"Predmety dlia liricheskogo poeta v nyneshnee vremia," ibid., 8:278-81 (text), 686-87 (variants), 793 (notes).

${ }^{23}$ Iazykov, "Zemletriasenie," Stikhotvoreniia i poemy, 338-39 (text), 558 (notes).

${ }^{24}$ Gogol', "Predmety," PSS 8:279.
} 
You will find words, phrases will be found, fires and not words will fly forth from you as from the ancient prophets, if only, like them, you will make this task your very own and most vital task, if only, like them, after scattering ashes on your head and rending your robes, you will entreat God with sobs to give you strength for the task, and will love the salvation of your land in the same way as they loved the salvation of their divinely chosen people..$^{25}$

In other chapters of Selected Passages, Gogol moved beyond this type of direct address; instead of exhorting Iazykov to emulate the Hebrew prophets by espousing biblical themes in his verse, he presented an apparently more objective assessment of his role as a model of the poet-prophet in the Russian literary tradition, as if Iazykov had already achieved this ideal. In "On the Lyricism of Our Poets" he cites Iazykov to support his broad assertion that Russian literature $i s$ intrinsically prophetic and biblical in spirit: "In the lyricism of our poets there is something that the poets of other nations do not possess, namelysomething close to the biblical ... the supreme triumph of spiritual sobriety." Leaving aside examples from Mikhailo Lomonosov and Gavrila Derzhavin, he claims that this special quality can be found "even in Pushkin," mentioning as evidence just three of his poems, including "The Prophet." ${ }^{\text {" }} 6$ He then rapidly moves on to the more congenial example of Iazykov, whose verse more clearly exhibits the required prophetic qualities. Significantly, he dwells at some length on "one of his youthful poems," "The Genius," quoting its full text to illustrate his argument. His choice of this particular poem in preference to a text by Pushkin can be explained by two factors: it draws a direct analogy between Russian writers and the Hebrew prophets and raises the all-important question of succession and continuity within a prophetic tradition.

Gogol's argument culminates in some general reflections on the unique prophetic character of Russian literature: "Why are neither France, nor England, nor Germany infected by this current, why do they not prophesy about themselves, but only Russia prophesies? Because she feels more strongly the hand of God in everything that befalls her and senses the coming of another kingdom. This is why our poets are beginning to sound biblical." ${ }^{27}$

A similar pattern can be detected in the penultimate chapter of Selected Passages, "What Then Finally Is the Essence of Russian Poetry and What Constitutes its Peculiarity." ${ }^{28}$ In this ambitious and sprawling essay, written over several years, burnt in 1845 , and eventually completed by October 1846, Gogol once more defines the unique essence of Russian poetry as biblical and prophetic and attempts to chart its past, present, and future course in relation to this defining criterion. Early in the essay, as evidence of the close

\footnotetext{
${ }^{25}$ Ibid., 281.

${ }^{26}$ Gogol', "O lirizme nashikh poetov" (first version 1845, second version 1846), PSS 8:248-61 (text), 677-82 (variants), 791-92 (notes). Quotes from p. 249. The other two poems cited were "V chasy zabav il' prazdnoi skuki..." (19 January 1830), one of Gogol's favorites, in which Pushkin was responding to an earlier poetic address from Metropolitan Filaret, and the posthumously published "Strannik" (1835), based on the first chapter of John Bunyan's The Pilgrim 's Progress.

${ }^{27}$ Gogol', "O lirizme nashikh poetov," PSS 8:251.

${ }^{28} \mathrm{Gogol}$ ', "V chem zhe nakonets sushchestvo russkoi poezii i v chem ee osobennost'," PSS 8:369-409 (text), 799801 (notes).
} 
relationship between Russian poets and the Hebrew prophets, he cites lines on the inspiration of "the divine prophet David" and Isaiah from an ode by Lomonosov. He carries on his survey through Derzhavin to Pushkin, singling out Iazykov among Pushkin's contemporaries for the strength and power of his poetic language. Significantly, he chooses to quote from some of the poems discussed above, in which Iazykov develops prophetic motifs connected with Pushkin. He quotes from "Trigorskoe," for example, and cites the line from "To the Poet," which builds directly on Pushkin's "The Prophet":

\section{Иди ты в мир - да слышит он пророка ${ }^{29}$}

Go forth into the world - may it hear the prophet

Gogol's purpose in quoting this line, however, is to underline the difference between Iazykov's view of the poet and Pushkin's approach. Although he concedes that the poem may be describing an ideal poet rather than a real one, he claims that Iazykov would not have been able to imagine a poet of this type, unless he possessed some degree of personal awareness of his own prophetic powers. Iazykov's poem about the poet as prophet is read as "proof" that its author was indeed a poet-prophet. Although Gogol regrets that Iazykov has recently lapsed from his high calling, he finds evidence in his late poem "The Earthquake" of the poet's desire to return to his "correct path."

In effect, therefore, in this essay Gogol is setting out a line of prophetic succession for Russian poets, which he traces from Lomonosov through Derzhavin to Iazykov, to a large extent bypassing Pushkin. His preference for Iazykov over Pushkin as a contemporary representative of the ideal of the Russian poet-prophet was not dictated just by the greater frequency of suitably "prophetic" themes in his verse: whereas Pushkin could no longer actively take up a place in a line of prophetic succession defined by Gogol, Iazykov was available as a living receptacle and vessel for Gogol's teachings. Gogol could no longer despatch letters to Pushkin, but he could still bombard Iazykov with unsolicited sermons, which enabled him to construct an image for himself and the wider public of a prophetic disciple and successor, ready to carry forward his injunctions and to apply them in real life.

We can see, therefore, that Gogol used a potent mixture of exhortation and example, drawn from the verse of both Pushkin and Iazykov, to persuade his readers of the validity of his claim that Russian literature was inherently prophetic. By establishing the analogy between Russian writers and Hebrew prophets on the basis of their common endeavor to articulate the messianic destiny of their peoples, he was instrumental in raising the personal, literary image of the writer as prophet to a higher level of national import. This aspect of his contribution, together with his own evident desire to assume a prophetic role within the tradition that he outlined, set the parameters for the approach later developed by Dostoevsky. By conferring prophetic powers on Iazykov, Gogol was indirectly elevating himself to the same status and writing himself into the line of prophetic succession. Although Dostoevsky chose to invoke Pushkin rather than Iazykov as his key "prophetic"

${ }^{29}$ Ibid., 387. In a letter to Iazykov of 2 April 1844, Gogol specifically asked Iazykov to send him the text of "Trigorskoe" and other works in connection with his plans for this essay (ibid., 12:279).

${ }^{30} \mathrm{Gogol}$, "V chem zhe," ibid., 8:390. 
predecessor (this was hardly surprising in view of the changed perception of Pushkin's stature in relation to his contemporaries), his underlying method for the validation of his prophetic ideal followed the pattern already set in place by Gogol.

\section{DOSTOEVSKY'S READING OF PUSHKIN}

Dostoevsky's relation to this tradition of validation is of particular interest for two reasons. He was the first author to go beyond the rather vague statements made by earlier writers about the poet's prophetic calling, attempting to define this claim more precisely by endowing Pushkin with a specific prophetic message. He was also the first writer to make explicit use of the notion of Pushkin as prophet to create a platform for the construction of his own prophetic image.

The best sources for reaching an understanding of Dostoevsky's contribution to this tradition are his Pushkin speech of 1880 and the complex of literary events that surrounded this occasion, including his public poetry readings. A close analysis of these materials reveals how Dostoevsky invoked the three key elements of the biblical tradition of prophetic validation (the principle of divine selection, endorsement by an earlier prophet, and public recognition) and incorporated them into a new literary context, focused on Pushkin.

Before we examine these sources, we should first dwell on the wider context of the Pushkin celebrations, since the mood of this occasion to a large extent determined the content of Dostoevsky's speech and its public reception. ${ }^{31}$ Plans to erect a monument to Pushkin in the garden of the litsei at Tsarskoe selo were first put forward in 1860; in the early 1870 s the project was transferred to Moscow. The statue was financed entirely by voluntary donations, collected from all over the country. ${ }^{32}$ It was accordingly seen as a truly national and popular undertaking, confirming the status of Pushkin as a "poet of the people," independent of the state. The unveiling of the statue was originally scheduled to take place on Pushkin's birthday (26 May); however, following the unexpected death of the tsar's wife on 22 May, it was deferred for an obligatory fortnight's state mourning. The atmosphere of anticipation was therefore intense; not only had this event been awaited for some twenty years, but everyone, including Dostoevsky, had already gathered in Moscow a fortnight before it took place. The transition from enforced official mourning to spontaneous national celebration served to reinforce the old antagonism between the tsar, aligned with the authority of the state, and the poet-prophet, cast as a representative of the people.

\footnotetext{
${ }^{31}$ For a full description of the programme of festivities from 5-8 June in Moscow (and also in St. Petersburg and the provinces), including newspaper reviews, telegrams, official addresses, and the text of speeches and poems, see Venok na pamiatnik Pushkina (St. Petersburg, 1880). A detailed account of the events of the first day is given on pp. 24-38.

${ }^{32} \mathrm{After}$ the first plan was put forward by graduates of the litsei in 1860, a model of the projected statue was made, but the funds collected were inadequate to proceed. When the plan was revived in 1870 , the committee, formed with the approval of the tsar in February 1871, decided to move the monument to Moscow. The location on Tverskoi boulevard opposite the Strastnoi Monastery was agreed in 1872. After two unsuccessful competitions, the choice was narrowed down to two models; Opekushin's work was finally selected in 1875. A total of 106,575 rubles was collected. See "Istoricheskii ocherk sooruzheniia pamiatnika Pushkinu," read by academician Ia. K. Grot on 5 June 1880, in Venok na pamiatnik Pushkinu, 197-204.
} 
The celebrations accordingly took on a general political character of opposition, as well as providing an informal battlefield on which hostile literary camps could parade their differences. ${ }^{33}$

The core of the celebrations took place over three days, from 6 to 8 June. Historians of Russian culture such as Victor Zhivov and Stephen Lessing Baehr have noted early examples of the ingrained Russian tendency to merge the categories of the sacred and the secular. ${ }^{34}$ This blurring of distinctions was certainly much in evidence in the manner in which the Pushkin celebrations were conducted: right from the beginning, the sacred was secularised and the secular was sacralised. On the first day of the celebrations, a large crowd gathered on Tverskaia square in front of Strastnoi Monastery to witness the unveiling of the statue (Dostoevsky informed his wife that windows overlooking the square had been hired out at fifty roubles apiece). ${ }^{35}$ Proceedings began in the monastery's adjoining church where a requiem mass was held in memory of the deceased poet. The atmosphere was not exactly that of a usual service, however. Access was by ticket only, and the church was full of carefully selected members of the intelligentsia and literary figures, most of whom were unaccustomed to worship and talked throughout the service. ${ }^{36}$ Dostoevsky was present and behaved very strangely, sidling up to one lady, transfixing her with his shining eyes, and entreating her to pray for him at his funeral as ardently as she was praying for Pushkin's soul. ${ }^{37}$ Metropolitan Makarii rounded off the service with a sermon in which he expressed gratitude to God for having enabled Pushkin to fulfil his mission to the Russian people and urged his congregants to pray "in the name of the entire Russian land" for the Lord to send more and more "people of genius and great men of action." ${ }^{38}$ Although the precise nature of Pushkin's mission to the Russian people was left undefined (this task fell to Dostoevsky), Makarii's comments offer an interesting indication of the extent to which the clergy was prepared to lend its support to the notion of Pushkin's prophetic role.

After these rousing words (which apparently received a rather lukewarm reception), the congregation trooped out on to the square, where a tent had been put up for the city dignitaries. ${ }^{39}$ When the shroud was removed from the statue, the assembled crowd gasped

\footnotetext{
${ }^{33}$ See the description of the mood of the occasion in N. N. Strakhov, "Vospominaniia o Fedore Mikhailoviche Dostoevskom," in F. M. Dostoevskii v vospominaniiakh sovremennikov, ed. K. Tiun'kin, 2 vols. (Moscow, 1990), 1:375-532(511). For Dostoevsky's view of the impending celebrations as a "battlefield" that he could not desert, where he had to see "our party" and "our idea" win over the "enemy party," see his letter of 28-29 May 1880 to A. G. Dostoevskaia, in F. M. Dostoevskii, Polnoe sobranie sochinenii v tridtsati tomakh (PSS), ed. V. G. Bazanov et al. (Leningrad, 1972-90), 30:1:169.

${ }^{34}$ See Victor Zhivov, "Religious Reform and the Emergence of the Individual in Russian Seventeenth-Century Literature," in Religion and Culture in Early Modern Russia and Ukraine, ed. Samuel H. Baron and Nancy Shields Kollmann (DeKalb, IL, 1997), 184-98; and Stephen Lessing Baehr, The Paradise Myth in Eighteenth-Century Russia: Utopian Patterns in Early Secular Russian Literature and Culture (Stanford, 1991), esp. 16-18, 27-29, $65-66$.

${ }^{35}$ Dostoevskii, letter to A. G. Dostoevskaia, 30-31 May 1880, PSS 30:1:170.

${ }^{36}$ Strakhov, "Vospominaniia," 1:507. A. I. Suvorina tartly characterized the occasion as a "congress, by ticket only, of course." See her "Iz vospominanii o Dostoevskom," in F. M. Dostoevskii v vospominaniiakh 2:425-32(425).

${ }^{37}$ Suvorina, "Iz vospominanii," 2:425-26.

${ }^{38}$ For the text of the speech see "Slovo mitropolita Makariia," in Venok na pamiatnik Pushkinu, 209-11(210-11).

${ }^{39}$ Strakhov, "Vospominaniia," 1:507.
} 
in awe before Pushkin, who stood before them "as if alive." heard, and then, to the sound of an orchestra playing a march from Giacomo Meyerbeer's opera Le Prophète under the direction of Nikolai Rubinshtein, wreathes were laid at the foot of the statue. ${ }^{41}$ The picture evoked by memoirists seems uncannily reminiscent of a scene of idol-worship, with the assembled crowd worshipping the effigy of Pushkin as if it were the object of a religious cult. In many of the poems written for the occasion, Pushkin is addressed as a "prophet," "poetic Messiah in Rus"” or "idol" (kumir), who has been "resurrected" for worship through his statue. ${ }^{42}$ Nikolai Strakhov, the former seminarist, even expressed disappointment that the statue was not sprinkled with holy water. ${ }^{43}$ Apparently the Church, in line with its general disapproval of sculpture as a pagan art form, had changed its original plan and refused to consecrate the "idol." 44

These details are all indicative of the quasireligious attitude of worship toward a secular phenemenon, which was such a prominent feature of the proceedings from the outset. Dostoevsky's speech, read on the third day of the celebrations (8 June), was no exception. It was described by many as a "sermon" (propoved') rather than speech; with its passionate emphasis on Pushkin as a sacred, prophetic writer, it fitted entirely into this pre-existent pattern. By presenting the founding father of Russian literature in this light, Dostoevsky evidently wished to demonstrate that a Russian writer could and should be a prophet. From here it was but one short step to the idea that Dostoevsky, as Pushkin's interpreter, was also his successor in the role of national prophet.

There is interesting evidence that Dostoevsky had been grooming himself self-consciously for the adoption of this role for some years. When Pushkin died, Dostoevsky was only fifteen. Nearly forty years later, he recalled his response to this event. In May 1837 he found himself travelling from Moscow to St. Petersburg together with his older brother. The journey was slow and tedious, and they filled the time with lofty dreams of the future and thoughts of poetry and poets; immediately upon arrival in St. Petersburg, they planned to go to the scene of Pushkin's fatal duel and to visit the poet's flat "to see the room in which he released his spirit." ${ }^{45}$ This plan is redolent of symbolic significance; it was as if, by breathing in the air where Pushkin expired, Dostoevsky could somehow lay claim to

\footnotetext{
${ }^{40}$ Venok na pamiatnik Pushkinu, 27.

${ }^{41}$ The music is noted in Marcus C. Levitt, Russian Literary Politics and the Pushkin Celebrations of 1880 (Ithaca, 1989), 85. Rubinshtein's choice of Meyerbeer's celebrated opera served to relate the notion of the individual's prophetic mission to a dissident stance of opposition to existing beliefs within a broad European historical context.

${ }^{42}$ See the section "Stikhi na otkrytie pamiatnika Pushkinu," in Venok na pamiatnik Pushkinu, 299-320. Thirteen different poets are represented. Explicit references to Pushkin as a "prorok" can be found in the poems of Ia. P. Polonsky, to whom the phrase "poeticheskii Messiia na Rusi" belongs (p. 301), and in two by I. Kondrat'ev (pp. 31819). Kondrat'ev describes Pushkin as a "prorok" who will live on as a "kumir" in the national memory (p. 319). Pushkin is described in terms that implicitly liken him to a prophet in the poems of A. N. Maikov (pp. 302-3), A. A. Golenishchev-Kutuzov (pp. 309-10), A. Iakhontov (p. 313), and M. (p. 315). Ia. P. Polonsky (p. 301) and N. S. Kurochkin (p. 304) both incorporate paraphrases of Pushkin's poem "Prorok" into their characterizations of the poet. For descriptions of Pushkin's statue as the poet himself, resurrected as an object of worship, see the lines "Pushkin sam, skul'ptorom voskreshen" (N. S. Kurochkin, p. 303), and "I zakhotel (narod) pered soboiu / Ego moguchii obraz voskresit', / ... I pamiatnik emu soorudit'. / ... Ego krase netlennoi poklonit'sia...”(A. Golenishchev-Kutuzov, p. 309).

${ }^{43}$ Strakhov, "Vospominaniia," 1:508.

${ }^{44}$ Levitt, Russian Literary Politics, 82-83.

${ }^{45}$ Dostoevskii, Dnevnik pisatelia (January 1876), in PSS 22:27-28.
} 
inheriting his sacred spirit. Although such thoughts were undoubtedly far from his conscious mind at the time, it is surely significant that he chose to recall this incident just when his own thoughts on Pushkin's prophetic role were beginning to gel. It is also interesting to note that Strakhov traces the formation of Dostoevsky's view of literature as a form of "preaching" (propovednichestvo) and of his own literary inspiration as "something transcendent, almost prophetic" back to the same period, when he was fifteen years old. ${ }^{46}$

When Dostoevsky came to read his speech on Pushkin, his prophetic aura was enhanced by various aspects of his performance; a contemporary description of his thin bent body, crumpled shirt, loose tie, and ungainly limp conjures up the figure of a social outcast, reminiscent of the hero of Lermontov's "The Prophet." ${ }^{\text {" }} 7$ He opened his speech by quoting from Gogol's early essay “A Few Words about Pushkin” (1832), thereby invoking the authority of one of the first writers to advance the notion of Pushkin's potential relevance to future generations. Significantly, he did not start from the beginning of Gogol's essay, but from the crucial definition of Pushkin as the quintessential embodiment of the Russian spirit; Gogol derived this view of Pushkin from the richness of his language, presented by him as the source of the poet's future potential. "Pushkin is an extraordinary phenomenon, and, perhaps, a unique phenomenon of the Russian spirit,' said Gogol. To this I would add: and a prophetic one. Yes, in his appearance, for all of us Russians, there is something indisputably prophetic." ${ }^{48}$

In his memoir of the occasion Dmitrii Liubimov drew attention to the special way that Dostoevsky read these opening sentences. When quoting Gogol, he spoke "somehow tonelessly" (kak-to glukho), but apparently pronounced his own comment on Pushkin's prophetic significance "in a loud whisper, somehow mysteriously." Liubimov felt himself and the entire audience tremble at the realization that the whole essence of Dostoevsky's speech was contained in the key word "prophetic" (implied, perhaps, but not actually used by Gogol in his essay). Dostoevsky, noting the effect that his words had produced, repeated for a second time the last sentence about the prophetic significance of Pushkin for the Russians. ${ }^{49}$ He then continued to develop this claim: "Pushkin appears just at the very beginning of our correct self-awareness, an awareness which had only barely begun and arisen in our society a whole century after the reforms of Peter the Great, and his appearance does much to illuminate our dark path with a new guiding light. In this sense Pushkin serves as a prophecy and a pointer." ${ }^{50}$

The description of Pushkin as the agent of "correct" national self-awareness, who illuminates the darkness and lights up the path ahead, suggests the figure of a prophet or Messiah rather than an ordinary writer. The argument that Dostoevsky uses to demonstrate this claim in his speech was first formulated a few years earlier in his Writer's Diary

${ }^{46}$ Strakhov, "Vospominaniia," 1:522.

${ }^{47}$ D. N. Liubimov, "Iz vospominanii," in F. M. Dostoevskii v vospominaniiakh, 2:406-19(414). Liubimov (18641942) was still a schoolboy of sixteen at the time of Dostoevsky's speech.

${ }^{48}$ Dostoevskii, "Pushkin (Ocherk)," PSS 26:136-49(136). The text of the speech, in Dostoevsky's Dnevnik pisatelia (August 1880) is preceded by an "Ob"iasnitel'noe slovo" (26:129-36) and followed by four lectures, replying to objections to the original talk (26:149-73).

${ }^{49}$ Liubimov, "Iz vospominanii," 2:415.

${ }^{50}$ Dostoevskii, "Pushkin (Ocherk)," PSS 26:136-37. 
of $1877 .{ }^{51}$ Reduced to its bare bones, it can be summarized in terms of three stages. First, Pushkin embodies the Russian spirit (this can be stated as an axiom, requiring no proof, as it rests on the "authority" of Gogol). Second, Pushkin's literary talent for producing poetic works in the spirit of other cultures therefore reflects an endemic spiritual quality of the Russian nation (once more, a literary text serves as the source of a spiritual ideal); here Dostoevsky cites the example of Pushkin's "Imitations of the Koran" and uses the quasimystical phrase "the reincarnation of his spirit in the spirit of other nations" to describe Pushkin's literary method in writing such imitations. ${ }^{52}$ Finally, this characteristic carries a deep prophetic significance for the Russian nation, whose mission consists of assimilating and reworking the legacy of other nations in order to return it to the rest of the world in a uniquely "spiritualized" Russian form.

According to Dostoevsky, Pushkin "in his prophetic foresight" embodied and made manifest Russia's genius, which lies in its "all-unifying, all-reconciling, and all-resurrecting" role in the history of humanity. ${ }^{53}$ This represents a curious transposition of Russian Orthodox Slavophile ideas onto the literary plane: just as the Russian nation, through its special God-bearing function, is destined to spread its true version of Christianity among the rest of the world, so Pushkin, through his alleged qualities of "universality and humanity" (vsemirnost' $i$ vsechelovechnost'), lights up the path ahead for both Russia and the rest of humanity. ${ }^{54}$ The name of Christ does not appear until the end of Dostoevsky's speech, but when it finally does it leaves no doubt that Pushkin represents an extension of Christ's mission to Russia, an embodiment of the nation's spiritual essence with a message for the rest of the world. In this way Dostoevsky succeeds in establishing the principle of the prophet's divine selection in relation to Pushkin. Furthermore, by attributing a message of his own making to the poet, he makes him appear to anticipate and therefore endorse his views, thereby upholding the biblical tradition of validation by an earlier prophet.

Recognizing that his words might seem exaggerated or fantastic, Dostoevsky then adds a telling comment: "If our idea is a fantasy, then with Pushkin there is at least something on which to base this fantasy." 55 This echoes his earlier point: "But this is not just a matter of poetry, nor just of artistic creation: if Pushkin had not existed ... our faith in our Russian independence of spirit, our now already conscious hope in our national strength, and our faith in our future independent mission in the family of European nations - all these would not have defined themselves, perhaps, with such unshakeable strength." ${ }^{15}$ This is a truly remarkable inversion of the order one might expect: the Messianic dream of Russia's national mission is validated in terms of its literary "incarnation" in Pushkin. ${ }^{57}$

\footnotetext{
${ }^{51}$ See Dostoevskii, "Pushkin, Lermontov i Nekrasov," in Dnevnik pisatelia (December 1877), in PSS 26:11319(114).

${ }^{52}$ Dostoevskii, "Pushkin (Ocherk)," PSS 26:146.

${ }^{53}$ Dostoevskii, "Pushkin, Lermontov i Nekrasov," PSS 26:114.

${ }^{54}$ Dostoevskii, "Pushkin (Ocherk)," PSS 26:148. Dostoevsky bases his claim on Tiutchev's poem, "Eti bednye selen'ia...," cited by him at this point in his speech (ibid.).

${ }^{55}$ Ibid.

${ }^{56}$ Ibid., 145.

${ }^{57}$ Pushkin is described as "nashego velikogo geniia, etu imenno ideiu v khudozhestvennoi sile svoei voploshchavshego" (ibid., 148, emphasis added).
} 
The concluding words of the speech focused the audience's mind on the question of a possible successor for Pushkin in the present. Ivan Turgenev, in his speech on the previous day, had already raised this question. Taking up the terms of Belinsky's old argument, he praised Pushkin's role as the first "national" (narodnyi) Russian poet, but disappointed his audience by stating that Pushkin had not reached the highest level of "national" (natsional'nyi) in the sense of "universal" (vsemirnyi) poet. At the end of his speech he invited speculation on Pushkin's successor: "Perhaps there will appear a new, still unknown chosen one, who will surpass his teacher and fully earn the title of national and universal poet which we cannot bring ourselves to confer on Pushkin, even though we do not dare to take it away from him. ${ }^{n 8}$

Turgenev would no doubt not have been averse to filling this post himself, but the tide of public opinion swung in the direction of Dostoevsky, who ended his speech on the following day by hinting at the same question in an oblique and suggestive manner, designed to redirect it toward the issue of prophetic succession: "Pushkin died at the very height of his powers and indisputably carried off with himself to the grave some great secret. And now without him we are trying to guess the meaning of this secret." ${ }^{\circ 9}$ Since Dostoevsky's speech had been entirely devoted to the unveiling of this mystery, it is hardly surprising that someone from the audience at this point let out a hysterical shriek of, "You have guessed it!" taken up first by women's voices and then by the whole audience with further shouts of "You have guessed it! You have guessed it!" 60 This public reaction served to confirm what had only been a latent suggestion in Dostoevsky's speech: his role as the self-appointed guardian, decipherer, and therefore heir of Pushkin's mysterious prophetic message.

This brings us to the all-important role of public recognition as the final stage in the validation of the prophet's status. Throughout his speech Dostoevsky was to a large extent playing along with his audience's feelings, while manipulating them in the process. As a perceptive memoirist noted at the time, the audience so much wanted to believe in the orator's message that it was prepared to suspend its logical judgment and to overlook any obvious contradictions in his argument. ${ }^{61}$ This attitude of eager receptivity goes some way to explaining the extraordinary public reaction to the speech. After its conclusion, bedlam ensued. Terms like "hysteria" and "frenzy" recur in the descriptions of what followed. Women screamed, a young man in tears fainted at Dostoevsky's feet, some people fell on their knees and kissed Dostoevsky's hands, while others wept and embraced each other (Turgenev was spotted advancing on his arch-enemy Dostoevsky to enfold him in a

${ }^{58}$ I. S. Turgenev, "Rech' po povodu otkrytiia pamiatnika A. S. Pushkinu v Moskve," in his Sochineniia, ed. M. P. Alekseev et al., 15 vols. (Moscow, 1960-68), 15:66-76(75). It is interesting to note that although Turgenev studiously avoids using the word "prophet" or "prophetic" in his speech, many of the qualities that he attributes to Pushkin are in fact those of the prophet: he emphasizes Pushkin's status as a poet of truth rather than of beauty, his role as a confirmation of the innate greatness of the Russian nation, and the liberating, elevating, moral force of his verse (ibid., 15:70, 76). In this way he prepared the audience for Dostoevsky's speech, which took up these ideas in a Slavophile and messianic context and openly ascribed a prophetic message to Pushkin.

${ }^{59}$ Dostoevskii, "Pushkin (Ocherk)," PSS 26:149.

${ }^{60}$ Liubimov, "Iz vospominanii," 2:418.

${ }^{61}$ G. I. Uspenskii, "Prazdnik Pushkina (Pis'ma iz Moskvy - iiun' 1880)," in F. M. Dostoevskii v vospominaniiakh 2:392-405(402-3). 
bear-hug). ${ }^{62}$ At one point it was even rumoured that Dostoevsky had suffered an epileptic fit after his speech and was dying (perhaps a somewhat macabre confirmation of his prophetic status?). ${ }^{63}$ Although one observer characterized the audience's response as pure "idol-worship," most of those who were present saw Dostoevsky quite uncritically as a saint or prophetic figure. ${ }^{64}$ According to one memoirist, he was "completely transfigured" while reading his speech and established a deep spiritual bond with his audience; another noted that he was "listened to as prophets were once listened to." ${ }^{65}$ His oratorical powers were compared by a journalist to those of St. Peter the Hermit (1050?-1115), one of the most eloquent and fiery preachers of the First Crusade. ${ }^{66}$ Another writer likened his magnetic power over the crowd to that of Savanarola (1452-98), the controversial Italian preacher and reformer, renowned for his prophecies. ${ }^{67}$ Closer to home, and based on actual observation of both figures, another memoirist compared Dostoevsky to his contemporary, the much-loved priest, preacher, and spiritual writer Ioann Kronshtadtsky (18291908 , canonized in 1989), whose immense popularity was reflected in his widespread adulation at public meetings. ${ }^{68}$

Dostoevsky was overwhelmed by the public reaction to his speech. In the detailed account that he despatched to his wife on the same day, he reported enthusiastically that he had been acclaimed a saint and prophet. Two old men, who had been implacable enemies for the last twenty years but made their peace after hearing his speech, came up to him and announced: "It is you who has reconciled us, you are our saint, you are our prophet!" This was apparently followed by shouts of "Prophet, prophet!" from the crowd. Dostoevsky further reported that Aksakov had hailed his speech as a "historical event;" like the sun, Dostoevsky's "word" was said to have dispelled clouds of darkness and spread understanding, brotherly love, and reconciliation among the people. ${ }^{69}$

Dostoevsky's ecstatic description of the reception of his speech as a "complete, absolutely complete triumph!" begs the question: a triumph for what? He had earlier identified the main issue at stake between warring literary camps as "the significance of Pushkin as the expression of the Russian national character" (russkoi narodnosti). ${ }^{70}$ Ostensibly, therefore, he was declaring that his camp had won the day as far as the issue of Pushkin's national significance was concerned. However, there was evidently another strong underlying element: Dostoevsky's sense of personal triumph at the public recognition of his

\footnotetext{
${ }^{62} \mathrm{Ibid} ., 2: 402$. This detail is recorded in Venok na pamiatnik Pushkinu, 61, and also figures in the accounts of a number of other memoirists. See, for example, A. F. Koni, "F. M. Dostoevskii," in F. M. Dostoevskii v vospominaniiakh 2:234-50(245); and Liubimov, "Iz vospominanii," 2:419. Dostoevsky also noted the incident in his letter to A. G. Dostoevskaia of 8 June 1880, PSS 30:1:185. For Turgenev's reaction see Liubimov, “Iz vospominanii," 2:418-19; and Suvorina, "Iz vospominanii," 2:427. Dostoevsky triumphantly reported this detail in his letter to A. G. Dostoevskaia of 8 June 1880 (PSS 30:1:184).

${ }^{63}$ Liubimov, "Iz vospominanii," 2:419.

${ }^{64}$ Uspenskii, "Prazdnik Pushkina," 2:401.

${ }^{65}$ Koni, "F. M. Dostoevskii," 2:244; Liubimov, "Iz vospominanii,” 2:418.

${ }^{66}$ I. F. Vasilevskii, Molva, 14 June 1880, cited in Dostoevskii, PSS 30:1:356 n.4.

${ }^{67}$ Koni, "F. M. Dostoevskii," 2:245. This comparison was rather less flattering. Although Savanarola was venerated almost as a saint by some followers, others saw him as a fanatic. Eventually the Pope forbade him to preach and excommunicated him. He was hanged as a schismatic and heretic on the market square in Florence.

${ }^{68}$ See Suvorina, "Iz vospominanii," 2:428.

${ }^{69}$ Dostoevsky, letter to A. G. Dostoevskaia, 8 June 1880, PSS 30:1:184-85.

${ }^{70}$ Ibid., 30:1:185; Dostoevsky, letter to A. G. Dostoevskaia, 28-29 May 1880 (ibid., 30:1:169).
} 
status as the legitimate successor to Pushkin in the role of national prophet. This was not an awareness that he would have suggested or admitted openly; he managed, however, to convey it indirectly (and therefore more convincingly) in a number of alternative ways.

One of the most effective strategies of this type involved Dostoevsky's direct and unmediated adoption of Pushkin's voice. We noted above that poetry occupies a privileged position in the hierarchy of texts, contributing to the tradition of literary prophecy. Among these texts, as we saw, Pushkin's "The Prophet" came to be regarded as the most authoritative; it was frequently invoked as the "proof" of Pushkin's status as poet-prophet and, beyond this, of the prophetic function of the Russian writer in general. Dostoevsky was particularly fond of reciting this poem and gave a number of public readings of it at the time of the Pushkin celebrations. At a literary-musical gathering held on the very evening following his speech, for example, he recited the poem twice in a row. The success of this reading led to two repeat performances in the autumn. Dostoevsky's wife recorded this sequence of events, underlining the extravagant public acclaim that greeted her husband's numerous "highly artistic" readings of the poem, described by her as a "real triumph for him." ${ }^{71}$

It is clear from other sources that Dostoevsky invested his readings of Pushkin's poem and of other works on prophetic themes with a profound autobiographical significance. Varvara Timofeeva, who met Dostoevsky while working on the proofs of Grazhdanin, recalls Dostoevsky reminiscing in 1873 about his time in prison following his arrest, when he received a copy of the Bible from his brother and first experienced a sense of "spiritual rebirth." 72 Dostoevsky would apparently accompany these recollections by reciting to her his favorite lines from Nikolai Ogarev's long autobiographical poem "The Prison" ("Tiur'ma," 1856-58). The extract that he usually recited ("in a low voice, with mystic delight on his face" $)^{73}$ incorporated a refrain, which describes the poet in prison, using the Bible to foretell the future (a custom also followed by Dostoevsky) ${ }^{74}$ and longing for a prophetic life and death:

Я в старой Библии гадал,

И только жаждал и вздыхал,

Чтоб вышла мне по воле рока

И жизнь, и скорбь, и смерть пророка ... ${ }^{75}$
In the old Bible I sought to guess the future, And could only long and sigh

That I should be granted by the will of fate

The life and grief and death of a prophet...

\footnotetext{
${ }^{71}$ After witnessing the success of Dostoevsky's reading of "The Prophet" during the Pushkin celebrations, V. P. Gaevskii invited him to read the same poem at two subsequent literary evenings in October 1880. SeeA. G. Dostoevskaia, Vospominaniia, ed. S. V. Belov and V. A. Tunimanov (Moscow, 1971), 351-52, 367-68.

${ }^{72} \mathrm{~V}$. V. Timofeeva (O. Pochinkovskaia), "God raboty s znamenitym pisatelem," in F. M. Dostoevskii v vospominaniiakh 2:137-96(184) and 2:510-12(notes). Varvara Timofeeva (1850-1931) first began working on the proofs of Grazhdanin in the spring of 1872 . Her recollections of this period were not written until the 1900s and were first published in 1904.

${ }^{73}$ Ibid., 2:184.

${ }^{74}$ Strakhov, for example, relates how Dostoevsky opened the Bible at random before his death and interpreted the passage that he came across as a prophecy or portent of his own imminent death (Strakhov, "Vospominaniia," 1:525).

${ }^{75}$ Cited from Timofeeva, "God raboty," 2:184. For the original version of these lines (slightly misquoted by Timofeeva) see "Tiur'ma (Otryvok iz moikh vospominanii)," in Stikhotvoreniia N. Ogareva (London, 1858), 41628(419-20). The refrain is repeated three times, in sections 3 (pp. 419-20), 6 (p. 423), and 9 (p. 428).
} 
Dostoevsky's fondness for these lines was evidently based on the parallel that he perceived between Ogarev's experience and his own time in prison. Ogarev wrote his poem soon after he arrived in London in 1856 to join Alexander Herzen. ${ }^{76}$ His recollection from the perspective of the late 1850s of his earlier arrest and imprisonment in 1834-35 is tinged with retrospective irony; this becomes explicit in the concluding section of his poem, where we learn that Tsar Nicholas now lies rotting in his grave, while the poet continues to work for his country from afar:

А я, выносливый певец,

Тружусь посильно издалёка,

Уже без гордости пророка,

Но тот же искренний боец,

Тружусь чтоб стали наконец

И правосудье, и свобода -

Уделом русского народа. ${ }^{77}$
And I, a long-suffering bard,

Labor from afar as my strength permits,

No longer with a prophet's pride,

But still the same sincere fighter,

I labor so that at last

Both justice and freedom

Should become the lot of the Russian nation.

Needless to say, these lines, with their ironic echo of Pushkin's "Arion" and prosaic repetition of the verb "I labor," somewhat undermine the earlier image of the ardent young Bible-reading poet-prophet, fired with post-Decembrist idealism. ${ }^{78}$ The irony, however, was evidently lost on Dostoevsky, who clearly wanted to revive the flagging "prophet's pride" and therefore presented the refrain as a direct continuation of more exalted earlier poems on this theme. According to Timofeeva, immediately after reading the extract from Ogarev, Dostoevsky would continue ("with flashing eyes and inspired gestures—-just like a priest before an invisible sacrificial altar") to declaim Pushkin's "The Prophet," followed by Lermontov's "The Prophet" of 1841. Not surprisingly, Dostoevsky ranked Pushkin's poem highest because of its transcendent quality ("it is almost above this world," he commented); in Lermontov's poem he found too much bitterness ("his prophet has a whip and poison"). ${ }^{79}$ Puskhin's prophet exemplified the purest strength of spirit, untainted by negative feelings of social alienation or bitterness.

Timofeeva later comments that Dostoevsky read poetry passionately, as if it were "his own personal confession." ${ }^{80}$ This was certainly true of his public recital of "The Prophet" a few years later during the Pushkin celebrations. He had in fact originally been scheduled

\footnotetext{
${ }^{76}$ The editorial notes in N. P. Ogarev, Stikhotvoreniia i poemy, ed. S. A. Reiser (Leningrad, 1956), 857-58, suggest that the poem was begun after Ogarev arrived in London in 1856 and completed at the beginning of 1858. Ogarev was the coeditor with Herzen of the pro-Decembrist literary almanac Poliarnaia zvezda (its cover carried the profiles of the five hanged Decembrists) and newspaper Kolokol. His verse includes several poems on the Decembrists. Ogarev and Dostoevsky met in Geneva in 1867; despite political differences they liked each other.

${ }^{77}$ Stikhotvoreniia N. Ogareva, 428.

${ }^{78}$ Ogarev's line "A ia, vynoslivyi pevets" contrasts with the lines from "Arion” (1827): "A ia, bespechnoi very poln" and "Lish' ia, tainstvennyi pevets." Pushkin's Arion, thrown aboard from the ship and separated from his companions, turns not to social activism but to the world of song (Pushkin, PSS 3/1:58 [text], 3/1:593-94 [variants], 3/2:1144 [notes]).

${ }^{79}$ Timofeeva, "God raboty," 2:184.

${ }^{80}$ Ibid., 2:185.
} 
to read Tiutchev's poem of 1837 on Pushkin's death at this occasion. ${ }^{81}$ With its characterization of Pushkin as a "divine vessel" (bozhestvennyi fial) or "living organ of the gods" (bogov organ zhivoi), marked by a holy fate, and with its closing promise that Russia would never forget her first love, this poem was a fitting choice: it allowed Dostoevsky, through the mouthpiece of Tiutchev, to address Pushkin from the perspective of later generations, while emphasizing the poet's divine qualities and holy mission. When Dostoevsky learned that the organizers wished him to read Pushkin's "The Prophet" instead, he was initially nervous; in almost every letter home to his wife, he wrote about it obsessively, anxious that his performance might not make the striking impression required for the grand finale of the celebrations. ${ }^{82}$

When it came to the actual evening, he gave "The Prophet" special prominence by declaiming it not once, but twice. ${ }^{83}$ Strakhov found his manner of reading "too sharp"; apparently his voice was raised to a shout, and he spoke "with such high-strung ecstasy that it was terrible to listen to." His emaciated body was gripped with tension; he convulsively held down his right hand, as if restraining himself from a gesture of prophetic command. ${ }^{84}$ According to his wife's notebooks, he put special emphasis on the words "coal" (ugl') and "burn" (zhgi), and uttered the verb "tore out" (vyrval) as sharply as possible. ${ }^{85}$ Another writer recalls that as he read the line, "And he took out the trembling heart" (I serdtse trepetnoe vynul), he held his hand out in front of him as if it contained his heart. ${ }^{86}$

Through these details of his performance, Dostoevsky emphasized the Russian tradition of poetry reading as an act of "reincarnation," whereby the reader is identified with the lyric persona of the poem and becomes linked with its author through this channel. Those present at Dostoevsky's public readings of "The Prophet" commonly reacted to his style of recital by seeing him as the very incarnation of Pushkin's prophet. "Before me was a great writer, who had suffered in his writings not just for me and for us, but for all people," Ekaterina Letkova-Sultanova recalled. "When he read 'The Prophet,' it seemed that he was the very person that Pushkin had seen before him when he wrote, 'With the word burn the hearts of people." ${ }^{87}$ The most remarkable thing about this passage is not so much the idea that the writer suffers "in his writings" for all humanity, as the notion that

81“"29-oe ianvaria 1837," in F. I. Tiutchev, Polnoe sobranie stikhotvorenii, ed. Georgii Chulkov, 2 vols. (Moscow, 1994), 1:248-49. For Dostoevsky's plan to read this poem see his letter to A. G. Dostoevskaia, 28-29 May 1880, in PSS 30:1:170.

${ }^{82}$ See Dostoevsky's letters of 2-3, 3-4, 7, and 8 June 1880, in PSS 30:1:175, 178, 183, 185.

${ }^{83}$ Strakhov, "Vospominaniia," 1:514. As noted above, Dostoevsky had already used the technique of emphasis through a repeated reading of the opening comment to his speech on Pushkin's prophetic significance.

${ }^{84}$ Ibid., 1:515.

${ }^{85}$ Leonid Grossman, Zhizn' i trudy F. M. Dostoevskogo: Biografiia v datakh i dokumentakh (Moscow, 1935), 302 .

${ }^{86}$ Koni, "F. M. Dostoevskii," 2:244. According to Koni, this reading of "The Prophet" took place "on the eve" of Dostoevsky's speech, that is, on 7 June.

${ }^{87}$ E. P. Letkova-Sultanova, “O F. M. Dostoevskom: Iz vospominanii,” in F. M. Dostoevskii v vospominaniiakh 2:443-62(446). The reading described most likely took place one year before the Pushkin celebrations, on 9 February 1879. 
Pushkin actually "saw" Dostoevsky before him when he was writing "The Prophet." The usual retrospective validation of Dostoevsky's prophetic status in terms of Pushkin is effectively turned on its head by making the originator of the tradition appear to endorse his own successor's prophetic role directly — in the same way as Elijah conferred his gift upon Elisha.

Another memoirist, Vladimir Posse, in a description of a later reading held on 19 October 1880, made the same link between Dostoevsky's sensitivity to suffering and his prophetic status. He took up the comparison of Dostoevsky to Pushkin's prophet quite literally, applying it every stage of the way: "Listening to 'The Prophet,' it seemed that it was Dostoevsky to whom the seraph appeared at the cross-roads of Russian life. His 'eyes were touched by him' - and 'his prophetic pupils opened wide, like a frightened eagle's."'

Posse continues in the same vein with regard to the fate of Dostoevsky's ears and tongue, but stops short at the more gruesome details of the torn out heart and burning coal. In his view, although Dostoevsky embarked on a process of prophetic initiation, he failed to complete it; he did not become a fully fledged prophet because he retained his heart:

"He split his chest with a sword," but ... after seeing the trembling of his poor suffering heart, the seraph refused to carry out the last commandment of the God who had sent him. He did not tear out the human heart and dropped from his hands the prophetic "coal, blazing with fire."

And out into the world set forth not a prophet, burning the hearts of people with the word, but a person with the eyes of a frightened eagle, a person, straining under the burden of unescapable human grief, a person with a split chest and a bared heart." $" 88$

It is in many ways astonishing that Dostoevsky's prophetic status should be decided on the basis of his relation to a poetic text, subjected to such a literal reading, rather than with reference to any more objective, external definition of prophecy. This example demonstrates that the Russian tradition of literary prophecy, although it invoked the biblical pattern of validation, remained essentially self-referential and tended to look inward for its own endorsement.

As well as public recitals of "The Prophet," one other strategy for reinforcing the image of Dostoevsky as Pushkin's prophetic successor deserves particular mention. This relates to the elaborate symbolism surrounding the bestowal of wreaths. After the conclusion of his speech, Dostoevsky was repeatedly called back on to the stage amid general hysteria; finally, he was presented with a huge laurel wreath, held up above his head by a group of young ladies. ${ }^{89}$ This ritual effectively transferred Pushkin's special status to Dostoevsky; as Strakhov noted, "in this way, Dostoevsky was honored as the hero of that day. ${ }^{900}$ Later that day the same wreath was delivered to Dostoevsky at his hotel. ${ }^{91}$ In the dark of the night, when the streets were almost deserted, Dostoevsky transported it to

${ }^{88} \mathrm{~V}$. A. Posse, "Iz knigi 'Moi zhiznennyi put',"” in F. M. Dostoevskii v vospominaniiakh 2:439-42(442).

${ }^{89}$ Slivitskii, "Iz stat'i ‘'Iz moikh vospominanii o L.I. Polivanove,”” 2:422; Venok na pamiatnik Pushkinu, 61.

${ }^{90}$ Strakhov, "Vospominaniia," 1:514.

${ }^{91}$ Slivitskii, "Iz stat'i ‘Iz moikh vospominanii o L. I. Polivanove,"” 2:422. 
Pushkin's statue, where he laid it at the feet of his "great teacher," bowing down to the ground in front of him. ${ }^{92}$ This highly charged symbolic gesture reflects Dostoevsky's determination to present himself as heir and successor to the prophetic poet: by bestowing his wreath upon Pushkin, he gave tangible expression to his sense of an indissoluble, continuous tradition of literary prophecy.

It is clear from these examples that the biblical model of Hebrew prophecy exerted a powerful formative influence on the Russian ideal of the writer as prophet. The adoption of this model led to the development of a range of strategies, designed to bring the validation of the writer's prophetic status more closely in line with its original source. In biblical tradition, as noted earlier, the prophet's status was confirmed on three levels: by divine selection, by an established prophet, and by public recognition. It remains to consider whether it is possible to detect a certain pattern or progression in the assimilation and adaptation of these three forms of endorsement in the successive stages of the Russian literary process of validation that we have surveyed.

It is in many ways remarkable that all the key elements necessary for the validation of the prophet's status in biblical tradition were already present in latent form and applied to the figure of the poet in lyric verse of the 1820s. Pushkin and Iazykov refer to the poet's inspiration as evidence of his divine selection, confer the title of prophet upon each other and upon their fellow poets, invoke biblical precedents, and even introduce a certain dimension of public recognition by conducting a poetic dialogue in verse, shared between intimate friends and opened up to a broader readership through publication. The potentially serious import of their references to the prophetic dimension of poetry was undermined, however, by their playful, sometimes ironic tone, as well as by their carefree mixing of classical and biblical images of prophecy. We should also note that the element of validation by public recognition, although present to a limited extent, did not extend beyond a very small circle of like-minded poets, friends, and readers.

Ultimately, Gogol was responsible for taking up this nascent tradition and developing it in a new direction. When he wrote to Iazykov, explaining to him that his poetic gift was of divine origin and that he should respond to his prophetic calling in the spirit of the Hebrew prophets, his tone was remorselessly earnest, without a trace of Pushkin's lightheartedness. As far as the principle of endorsement by an earlier prophet was concerned, the passage of time from the 1820s to the mid-1840s, divided by the watershed of Pushkin's death, enabled Gogol to introduce a new perspective of retrospective validation, reaching back to Lomonosov and Derzhavin, alluding to Pushkin's prophetic potential, but preferring to concentrate on Iazykov as the prime focus of his hopes for the realization of the ideal of the poet-prophet in contemporary literature.

In addition, by extending the tradition of literature as prophecy from verse into prose, Gogol developed the role played by public recognition of the prophet's status. While continuing to present poems as the principal sacred texts of literary prophecy, he opened the door to other writers to take up their place in the tradition by addressing the public

${ }^{92}$ Dostoevskaia, Vospominaniia, 365. 
with a broader prophetic message, based on earlier verse texts but elaborated in prose. This aspect of his role is well illustrated by his presentation of Iazykov's "The Genius" as "proof" that the biblical model of prophetic succession from Elijah to Elisha was applicable to the Russian literary process, and by his evident desire to implement this model in his own life. A similar shift from the private to the public domain was reflected in his rewriting of his personal correspondence for publication in book form.

Dostoevsky's Pushkin speech reflects an even fuller development of all three elements of the biblical model for prophetic validation. With his presentation of Pushkin as a Christ figure, chosen by God to embody the spirit of the Russian nation and to spread its prophetic message to the rest of the world, Dostoevsky took the notion of the poet-prophet's divine selection to a new extreme. Whereas Gogol's comments on the prophetic qualities of Russian literature were related to a range of different authors and scattered throughout his correspondence, Dostoevsky put forward the idea of a single originating poet-prophet for the Russian tradition in a more concentrated form, centered on Pushkin. He used the image of the poet-prophet that he constructed for Pushkin more explicitly to validate his own prophetic status as the poet's sucessor. He also cultivated the dimension of public recognition much more fully than Gogol, using a powerful combination of tactics to reach a wider audience: the public speech, delivered in a private, confessional tone, its broad dissemination through the popular form of The Writer's Diary, and highly charged and emotional readings of "The Prophet" in front of large gatherings. These varied genres of writing and performance all enabled him in different ways to bridge the gap between the intimate, personal attribute of prophetic intuition and its validation through public recognition.

We can see, therefore, that all three elements of the biblical model for validation of the prophet's status were taken up by a succession of Russian writers and developed in a manner that reflects a clear progression from an inital latent presence to a later more direct invocation. The fundamental source of the appeal of the image of the Hebrew prophet evidently resided in the authority that it conferred upon the individual writer: the authority of belonging to a chain of writers, reaching back to the Hebrew prophets; the authority of transmitting a literary message, based on the word of God; the authority of articulating the nation's messianic destiny; and, ultimately, the authority of transcending time by gaining a place in sacred history. Although considerable distortion was involved in the attempt to validate an essentially self-referential and self-authenticating secular tradition of literary prophecy by presenting it as the continuation of a religious tradition based on revelation, this process, once established and set in motion, had a powerful impact on the dynamics of the Russian literary tradition and on the authority ascribed to this tradition by successive generations of writers, readers, and critics. 